\title{
Expression of thyroid hormone receptors $A$ and $B$ in developing rat tissues; evidence for extensive posttranscriptional regulation
}

\author{
Richard Keijzer ${ }^{1, *}$, Piet-Jan E Blommaart ${ }^{1,2, \star}$, Wil T Labruyère ${ }^{2}$, Jacqueline L M Vermeulen ${ }^{2}$, \\ Behrouz Zandieh Doulabi ${ }^{3}$, Onno Bakker ${ }^{3}$, Dick Tibboel ${ }^{1}$ and Wouter H Lamers ${ }^{2}$
}

\author{
${ }^{1}$ Department of Pediatric Surgery, Erasmus MC-Sophia, Dr Molewaterplein 60, 3015 GJ Rotterdam, The Netherlands \\ ${ }^{2}$ Department of Anatomy and Embryology, Academic Medical Center, University of Amsterdam, Meibergdreef 69-71, 1105 AZ Amsterdam, The Netherlands \\ ${ }^{3}$ Academic Medical Center, University of Amsterdam, Meibergdreef 9, 1105 AZ Amsterdam, The Netherlands
}

(Requests for offprints should be addressed to W H Lamers who is now at AMC Liver Center, Academic Medical Center, University of Amsterdam, Meibergdreef 69-71, 1105 BK, Amsterdam, The Netherlands; Email: w.h.lamers@amc.uva.nl)

(R Keijzer and P-J E Blommaart contributed equally to this study)

\begin{abstract}
The perinatal changes in the pattern of expression of the thyroid hormone receptor (TR) isoforms $T R \alpha_{1} \mathrm{TR} \alpha_{2}, \mathrm{TR} \beta_{1}$, and TR $\beta_{2}$ were investigated using in situ hybridization and immunohistochemistry, and RT-PCR and western blotting as visualization and quantification techniques respectively. In liver, lung, and kidney, TR $\alpha$ mRNA was expressed in the stromal and TR $\beta$ mRNA in the parenchymal component of the tissues. When compared with liver, TR $\alpha$ mRNA concentrations were tenfold higher in lung, kidney, and intestine, and 100-fold higher in brain, with TR $\alpha_{2}$ mRNA concentrations exceeding those of TR $\alpha_{1} 5$ to 10-fold. Tissue TR $\beta_{1}$ mRNA concentrations were similar in liver, lung, and brain, and 3- to 5-fold higher in kidney and intestine. None of the TR $\beta_{2}$ mRNA could be detected outside the pituitary. Tissue $T R \alpha_{2}$ and $T R \beta_{1}$ protein levels reached adult levels at 5 days before birth, whereas $T R \alpha_{1}$ protein peaked after birth. Because of the distinct time-course of thyroid hormonebinding receptors $T R \alpha_{1}$ and $T R \beta_{1}$, we speculate that an initiating, $T R \beta_{1}$-mediated signaling from the parenchyma is followed by a $\operatorname{TR} \alpha_{1}$-mediated response in the stroma. When compared with organs with a complementary parenchymal-stromal expression pattern, organs with extensive cellular co-expression of TR $\alpha$ and TR $\beta$ (brain and intestinal epithelium) were characterized by a very low TR $\alpha$ protein: mRNA ratio, implying a low translational efficiency of TR mRNA or a high turnover of TR protein. The data indicate that the TR-dependent regulatory cascades are controlled differently in organs with a complementary tissue expression pattern and in those with cellular co-expression of the TR $\alpha$ and TR $\beta$ genes.
\end{abstract}

Journal of Molecular Endocrinology (2007) 38, 523-535

\section{Introduction}

Since it was discovered that metamorphosis can be induced in amphibians by feeding them thyroid gland extract (Gudernatsch 1912), it has become generally accepted that thyroid hormones play a crucial role in controlling growth, development, differentiation, and metabolism of virtually all tissues of vertebrates. The beneficial effects of thyroid hormones on perinatal organ development and maturation are most readily recognizable in brain (Oppenheimer \& Schwartz 1997, Morreale de Escobar et al. 2004). However, since thyroid hormones can pass the placenta and accumulate in embryonic cells to functionally relevant concentrations well before the embryonic thyroid starts to function on its own (Morreale de Escobar et al. 1990), thyroid hormone-dependent instructive effects in earlier phases of organ development are likely (Glinoer 2001, van Tuyl et al. 2004).
The effects of thyroid hormones on gene expression are mediated via the thyroid hormone receptor (TR) genes $\alpha$ (NR1A1) and $\beta$ (NR1A2), which are both the members of the steroid/TR superfamily of liganddependent transcription factors (Zhang \& Lazar 2000, Yen 2001, Yen et al. 2006). The TR $\alpha$ and TRß genes generate, via alternative splicing, four thyroid hormone-binding receptors, namely $\operatorname{TR} \alpha_{1}$ and TR $\beta_{1-3}$ (Williams 2000, Chassande 2003). In addition, several proteins, including $\mathrm{TR} \alpha_{2}$, which do not bind thyroid hormone-response elements and/or thyroid hormones, are formed. Presumably, these proteins modulate thyroid hormone-mediated gene expression (Cheng 2000, Williams 2000, Plateroti et al. 2001, Yen 2001).

In rat, northern blot analysis showed that $\mathrm{TR} \alpha \mathrm{mRNA}$ concentration increased in brain, liver, and brown adipose tissue from 18 days of development onwards to 
reach its highest level perinatally (Strait et al. 1990, Tuca $e t$ $a l .1993)$. TR $\beta$ mRNA also increased perinatally in brain, but was reported to reach its peak only in the second postnatal week (Strait $e$ t al. 1990). In contrast, TR $\beta$ mRNA decreased perinatally in liver and brown adipose tissue (Strait et al. 1990, Tuca et al. 1993). In the developing nervous system of the rat, the highest cellular concentration of TR $\alpha$ mRNAs was found in the areas of neuronal differentiation such as the fetal neocortical plate, whereas TR $\beta$ mRNAs were largely restricted to the zones with neuroblast proliferation, such as the germinal trigone and the cortical ventricular layer (Bradley et al. 1992). Although these findings suggested complementary and, perhaps, mutually exclusive roles of the $T R \alpha$ and $T R \beta$ genes in organogenesis, they did not result in a specific hypothesis for the mechanism of action of thyroid hormones in development. Furthermore, these studies did not address TR expression at the protein level. We, therefore, studied the spatial and the temporal distribution of the mRNAs and proteins encoding TR $\alpha$ and TR $\beta$ by in situ hybridization and immunohistochemistry. Since our in situ probes did not differentiate between the respective splice variants, quantitative PCR techniques were used to determine the tissue levels of $\mathrm{TR} \alpha_{1}, \mathrm{TR} \alpha_{2}$, $\mathrm{TR} \beta_{1}$, and TR $\beta_{2}$ mRNA. Since tissue TR mRNA level and nuclear thyroid hormone-binding capacity (i.e., functional TR protein) do not always correlate (Strait $e t$ $a l$. 1990, Tuca et al. 1993), we also investigated tissue TR protein level by western blot analysis and immunohistochemistry, using our recently described antisera (Zandieh Doulabi et al. 2002, 2003). We report a highly specific, but heterogeneous spatial and temporal expression pattern of the TR $\alpha$ and TR $\beta$ mRNAs, and report evidence for extensive posttranscriptional regulation in the perinatal period.

\section{Materials and methods}

\section{Animals}

Female Wistar rats in heat were selected and mated in the morning, the next day being designated embryonic day 1 (E1). Fetuses were harvested by caesarian section at E13, E14, E15, E16, E17, E18, E19, and E20; or were born naturally and killed 1 (P1) or 4 days (P4) later, or as adults. All experiments were performed under protocols approved by the University of Amsterdam Committee on Animal Research.

\section{Tissue isolation and preparation}

All tissues were fixed in phosphate-buffered $4 \%$ formaldehyde for in situ hybridization and in the ratio of methanol:acetone:water $(2: 2: 1(\mathrm{v} / \mathrm{v}))$ for immunohistochemistry as described (van Tuyl et al. 2004).

\section{In situ hybridization}

In situ hybridization was carried out exactly as described (Moorman et al. 2000). In situ hybridization carried out according to this protocol produces semiquantitative data, that is, differences in absorbance between different tissues or cells within one section reflect differences in mRNA concentration between these tissues or cells (Jonker et al. 1997). This protocol is included in the method paper referenced to Moorman et al. (2000). The EcoRI-HindIII cDNA fragments of the clones rc-erbA- $\alpha$ (nt -29 to +1821$)$ and rc-erbA- $\beta$ (nt -37 to +2165 ) were used as probes to detect TR $\alpha$ and TR $\beta$ mRNA respectively (Bradley $e t$ al. 1992). These fragments do not discriminate between TR isoforms. $\left[\alpha^{-35}\right.$ S $]$ UTP-labeled antisense and sense probes were generated with Sp6 and T7 RNA polymerase respectively. We opted to use almost the entire TR mRNA sequence to make the in situ assay as sensitive as possible, because the hybridization signal is dependent on the length of the probe (before fragmentation). We then used PCR to quantify subtypes.

\section{Quantitative PCR}

At E15, E18, P1, and in the adult, TR mRNA levels were quantified in brain, pituitary gland, lung, liver, kidney, and intestines. For each stage, minimally three rats were assayed. TR mRNAs were quantified by establishing the efficiency of both the reverse-transcription and polymerase chain reaction steps of the assay. Large-scale mRNA synthesis from the respective TR cDNA fragments was performed with the MEGAshortscript T7 Kit (Ambion, Nieuwerkerk a/d IJssel, The Netherlands) and quantified by including a known amount of $\left[\alpha_{-}{ }^{35} \mathrm{~S}\right] \mathrm{CTP}$. Reverse-transcriptase efficiency was estimated by comparing mRNA input (different amounts of the RNA transcripts) and DNA output, and amounted to $80-100 \%$. TR $\alpha$ cDNA amplification was estimated by competitive RT-PCR as described (Moller \& Jansson 1997), whereas TR $\beta$ cDNA amplification was measured by real-time PCR (Lightcycler, Roche).

\section{$\operatorname{TR} \alpha$}

The sense primer was chosen in the common part of the $T R \alpha_{1}$ and $T R \alpha_{2}$ sequences, whereas the antisense primers were in the specific parts. For $\mathrm{TR} \alpha_{1}$, a $343 \mathrm{bp}$ fragment was formed (nt 1219-1562 of the mRNA) and for $\mathrm{TR}_{2}$ a $242 \mathrm{bp}$ fragment (nt 1411-1653). After reverse transcription (RT) and PCR amplification, the concentration of $\mathrm{TR} \alpha_{1}$ and $\mathrm{TR} \alpha_{2} \mathrm{cDNA}$ in the sample was estimated by titration of $8-5000 \times 10^{-4}$ amol $\left(\mathrm{TR} \alpha_{1}\right)$ or $4-2500 \times 10^{-3}$ amol $\left(\mathrm{TR} \alpha_{2}\right)$ of a "competimer' fragment that differed from the parent fragments by missing an identical $82 \mathrm{bp} 5^{\prime}$ HincII fragment. 
The amount of competimer added was determined by including a known amount of $\left[\alpha^{-35} \mathrm{~S}\right] \mathrm{dATP}$ during large-scale PCR synthesis. TR $\alpha$ mRNA concentration in the sample was calculated from a double logarithmic plot of the TR $\alpha$ :competimer ratio and the competimer concentration (Moller \& Jansson 1997).

\section{$\operatorname{TR} \beta$}

The antisense primer was chosen in the common part of $\operatorname{TR} \beta_{1}$ and $\operatorname{TR} \beta_{2}$, whereas the sense primers were in the specific part. For $\mathrm{TR} \beta_{1}$, a $185 \mathrm{bp}$ fragment was formed (nt 437-622 of the mRNA) and for TR $\beta_{2}$, a $244 \mathrm{bp}$ fragment (nt 343-587 of the mRNA). TR $\beta$ cDNA concentration in the sample was deduced from a standard curve with $5-50000 \times 10^{-4}$ amol TR $\beta_{1}$ or TR $\beta_{2}$ DNA fragment. The $\mathrm{TR} \beta_{1}$ and TR $\beta_{2}$ fragments were made by large scale PCR synthesis and quantified by including a known amount of $\left[\alpha^{32} \mathrm{P}\right]$ dATP. TR $\beta_{2}$ levels were also quantified with fluorescence resonance energy transfer of hybridization probes nt 264-290 (red640-labeled) and nt 292-316 (fluorescein-labeled) on amplified fragment nt 241-556. Dilutions of pituitary gland mRNA with a predetermined $\mathrm{TR} \beta_{2}$ mRNA concentration were used to generate a standard curve.

\section{Western blotting and immunohistochemistry}

Extracts of brain, pituitary gland, thyroid, trachea, lung, heart, muscle, liver, intestines, kidneys, adrenals, testis, epididymal fat pad, bladder, and spleen from $3 \mathrm{E} 17$, P4, and adult rats were analyzed in triplicate by western blotting, using antisera specifically identifying $\mathrm{TR} \alpha_{1}$, $\mathrm{TR} \alpha_{2}$, and $\operatorname{TR} \beta_{1}$. The specificity of the antibodies used was described previously (Zandieh Doulabi et al. 2002, 2003). The extracts were prepared in $0.25 \mathrm{M}$ sucrose, $40 \mathrm{mM}$ dithiothreitol, $2 \%$ SDS, $1 \mathrm{mM}$ EDTA, $62.5 \mathrm{mM}$ Tris- $\mathrm{HCl}(\mathrm{pH} 7 \cdot 6)$, and $10 \%$ glycerol, separated on $10 \%$ $(\mathrm{w} / \mathrm{v})$ polyacrylamide gels, and blotted onto an Immobilon-P (Millipore) membrane. After staining with amido black to verify similar protein loading, the membrane was incubated in $10 \mathrm{mM}$ Tris- $\mathrm{HCl}(\mathrm{pH} 8 \cdot 0), 150 \mathrm{mM} \mathrm{NaCl}$, $0.5 \%$ Tween 20 , and $5 \%$ nonfat dried milk powder (Natrinon, Nutricia) for $6 \mathrm{~h}$, followed by an overnight incubation in a ratio of 1:1000 dilution of the respective antisera. Antibody binding was quantified using chemiluminescence (CDP-Star, Roche), in combination with the LUMI-imager F1 (Roche; Bakker 1998). In the absence of primary antisera, no staining was seen, whereas in their presence, bands at the anticipated $M_{r}$ of the corresponding receptors appeared. However, in liver and kidney extracts, extra bands at both higher and lower $M_{r}$ than found in other organs were observed for $\mathrm{TR} \alpha_{1}$ and $\mathrm{TR} \beta_{1}$. These patterns were also found in organs that were rapidly isolated and analyzed immediately.

Immunoperoxidase staining was performed on dewaxed tissue sections. Antibody binding on sections was visualized by the indirect unlabeled antibody peroxidase anti-peroxidase (PAP) method (Sternberger et al. 1970). PAP immunocomplexes were purchased from Nordic (Tilburg, The Netherlands). If care is taken not to overdevelop

Table 1 Developmental changes in the expression of thyroid hormone receptors (TRs) in the central nervous tissue, lung, liver, kidney, adrenal, and intestines

\begin{tabular}{|c|c|c|c|c|c|c|c|c|c|}
\hline & \multirow[t]{2}{*}{$\begin{array}{l}\text { Stage of } \\
\text { development }\end{array}$} & \multicolumn{2}{|l|}{$\operatorname{TR} \alpha_{1}$} & \multicolumn{2}{|l|}{$\operatorname{TR} \alpha_{2}$} & \multicolumn{2}{|l|}{ TR $\beta_{1}$} & \multicolumn{2}{|l|}{$\operatorname{TR} \beta_{2}$} \\
\hline & & mRNA & Protein & mRNA & Protein & mRNA & Protein & MRNA & Protein \\
\hline \multirow{3}{*}{$\begin{array}{l}\text { Organ } \\
\text { Central } \\
\text { nervous system }\end{array}$} & Early fetal & - & - & + & - & - & - & - & - \\
\hline & Late fetal & - & - & + & - & - & ++ & - & - \\
\hline & Neonatal & - & - & ++ & - & ++ & ++ & - & - \\
\hline \multirow[t]{3}{*}{ Lung } & Early fetal & - & - & ++ & + & + & - & - & - \\
\hline & Late fetal & - & + & ++ & - & ++ & + & - & - \\
\hline & Neonatal & - & + & + & - & + & + & - & - \\
\hline \multirow[t]{3}{*}{ Liver } & Early fetal & - & - & ++ & - & - & - & - & - \\
\hline & Late fetal & + & + & + & + & ++ & ++ & - & - \\
\hline & Neonatal & - & + & + & + & + & + & - & - \\
\hline \multirow[t]{3}{*}{ Kidney } & Early fetal & - & - & + & - & - & - & - & - \\
\hline & Late fetal & - & + & + & - & + & + & - & - \\
\hline & Neonatal & - & + & + & - & + & + & - & - \\
\hline \multirow[t]{3}{*}{ Adrenal } & Early fetal & + & - & + & - & - & - & - & - \\
\hline & Late fetal & + & + & + & ++ & - & + & - & - \\
\hline & Neonatal & - & + & - & ++ & - & - & - & - \\
\hline \multirow[t]{3}{*}{ Intestines } & Early fetal & - & - & - & - & - & - & - & - \\
\hline & Late fetal & - & + & ++ & - & + & + & - & - \\
\hline & Neonatal & - & - & + & + & + & + & - & - \\
\hline
\end{tabular}

Early fetal, E12-E16; late fetal, E17-E22; neonatal, P0-P4. -, no expression detected; +, well detectable expression; ++, strong expression. 
the enzymic staining, local differences in immunohistochemical staining intensity represent differences in protein concentration between these cells or tissues (van Straaten et al. 2006).

\section{Results}

\section{Distribution of TR $\alpha$ and TR $\beta$}

We describe the expression patterns TR $\alpha$ and TR $\beta$ for each organ separately, going from mRNA to protein and from early fetal to postnatal. An overview of our findings is provided in Table 1 .

\section{Central nervous system}

The staining pattern of TRs in the central nervous system has been described (Bradley et al. 1992). In agreement, TR $\alpha$ mRNA expression in the basal plate of the neural tube was already pronounced at E15 (Fig. 1A) and very strong in the cortical plate of the brain at E16 (Fig. 1C). In contrast, TR $\beta$ mRNA expression was undetectable (Fig. 1B) or much weaker (Fig. 1D). Since the TR $\alpha_{2}$ mRNA concentration exceeded that of $\mathrm{TR} \alpha_{1}$ more than 20-fold (Fig. 2A), it was responsible for the observed TR $\alpha$ mRNA expression pattern. The expression of $\mathrm{TR} \alpha_{2}$ and $\mathrm{TR} \beta_{1}$ mRNA followed a similar temporal pattern and was highest at P1 (Fig. 2A). TR $\beta_{2}$ mRNA was not detectable. Both before and shortly after birth, the $\mathrm{TR} \alpha_{1}$ and $\mathrm{TR} \alpha_{2}$ protein concentration in the brain (Fig. $1 \mathrm{G}, \mathrm{H}, \mathrm{J}$ and $\mathrm{K}$ ) was very low when compared with that in the other organs (Fig. 3A-F). In contrast, $\mathrm{TR} \beta_{1}$ protein was already present in fetal brain (E17) and abundant at P4 (Figs 1I, L and 3). These data show that the developing brain was characterized by a very low protein: mRNA ratio for $\mathrm{TR} \alpha_{1}$ and, in particular $\mathrm{TR} \alpha_{2}$, whereas this ratio was much higher for $\mathrm{TR} \beta_{1}$. A summary of these findings can be found in Table 1 .

\section{Other intracranial organs}

TR $\alpha$ and TR $\beta$ expression colocalized at many sites in the central nervous tissue. In the inner ear, however, the strong signal of TR $\beta$ mRNA in the sensory epithelium of the cochlea and the very weak signal in the cochlear nerve (Fig. 1F) contrasts with the opposite staining pattern TR $\alpha$ mRNA (Fig. 1E) and demonstrates the specificity of the in situ hybridization procedure. We have included this result as an example of the sometimes highly contrasting TR expression patterns in organs.

Protein for all the three receptors was observed in the extracts of adult pituitary glands (Fig. 3A, D and I). $\mathrm{TR} \beta_{1}$ protein was present in E18 and P4 pituitary
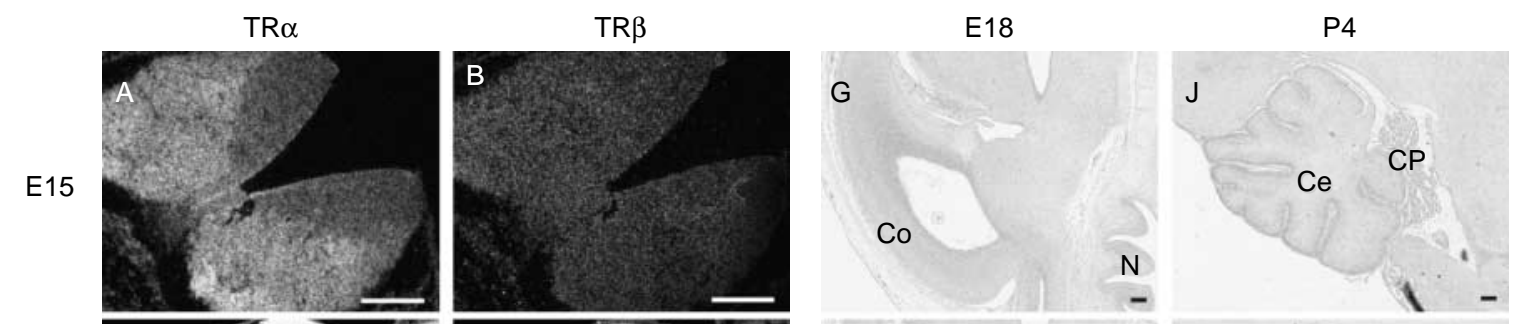

$\mathrm{TR} \alpha 1$
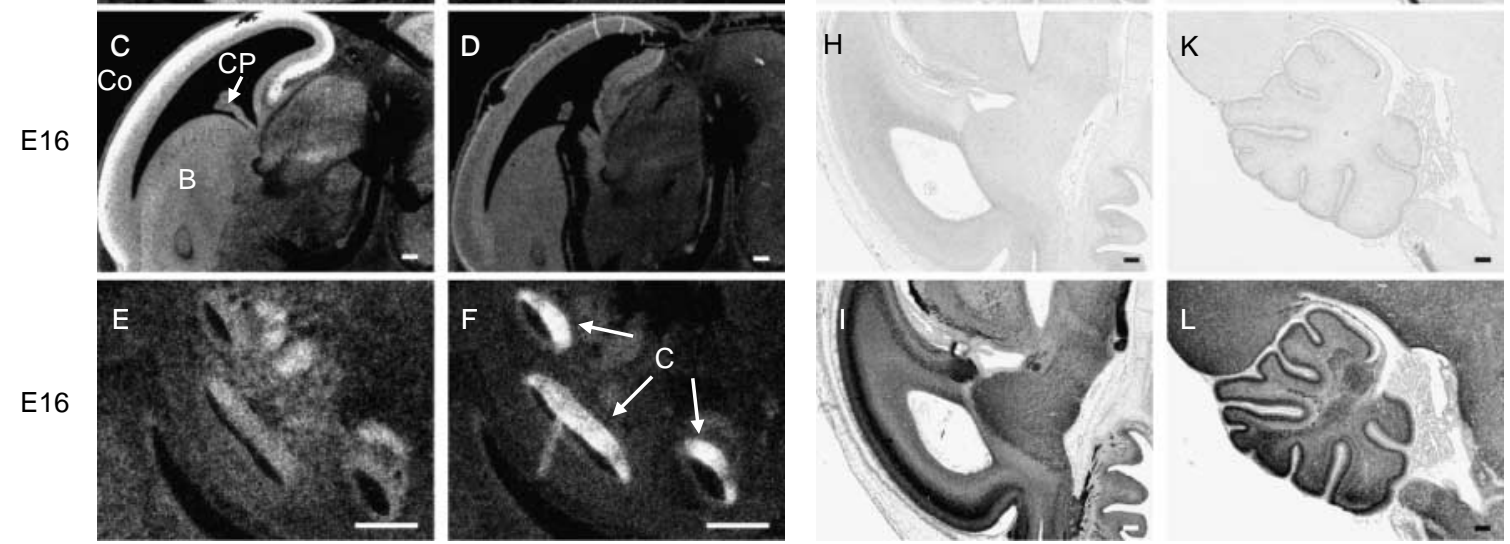

TR $\alpha 2$
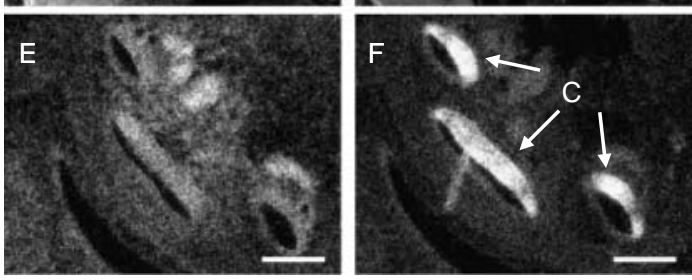

Figure 1 Thyroid hormone receptor expression in perinatal central nervous system. TR $\alpha$ mRNA appears in the basal plate of the E15 spinal cord (A) well before TR $\beta$ mRNA (B). In the E16 brain, TR $\alpha$ mRNA expression in the cortical plate (C) is much stronger than TR $\beta$ expression (D). In contrast, the TR $\beta$ signal is intense in the cochlear sensory epithelium (F), whereas TR $\alpha$ expression dominates in the cochlear nerves $(E)$. At E18 and $P 4$, protein expression of $T R \alpha_{1}$ and $T R \alpha_{2}$ is very low $(\mathrm{G}, \mathrm{H}, \mathrm{J}$ and $\mathrm{K})$. In contrast, TR $\beta_{1}$ protein is highly expressed in various structures of the brain (I and L). B, basal nuclei; C, cochlea; Ce, cerebellum; Co, cortex; CP, choroid plexus; $\mathrm{N}$, nose. Bar, $100 \mu \mathrm{m}$. 

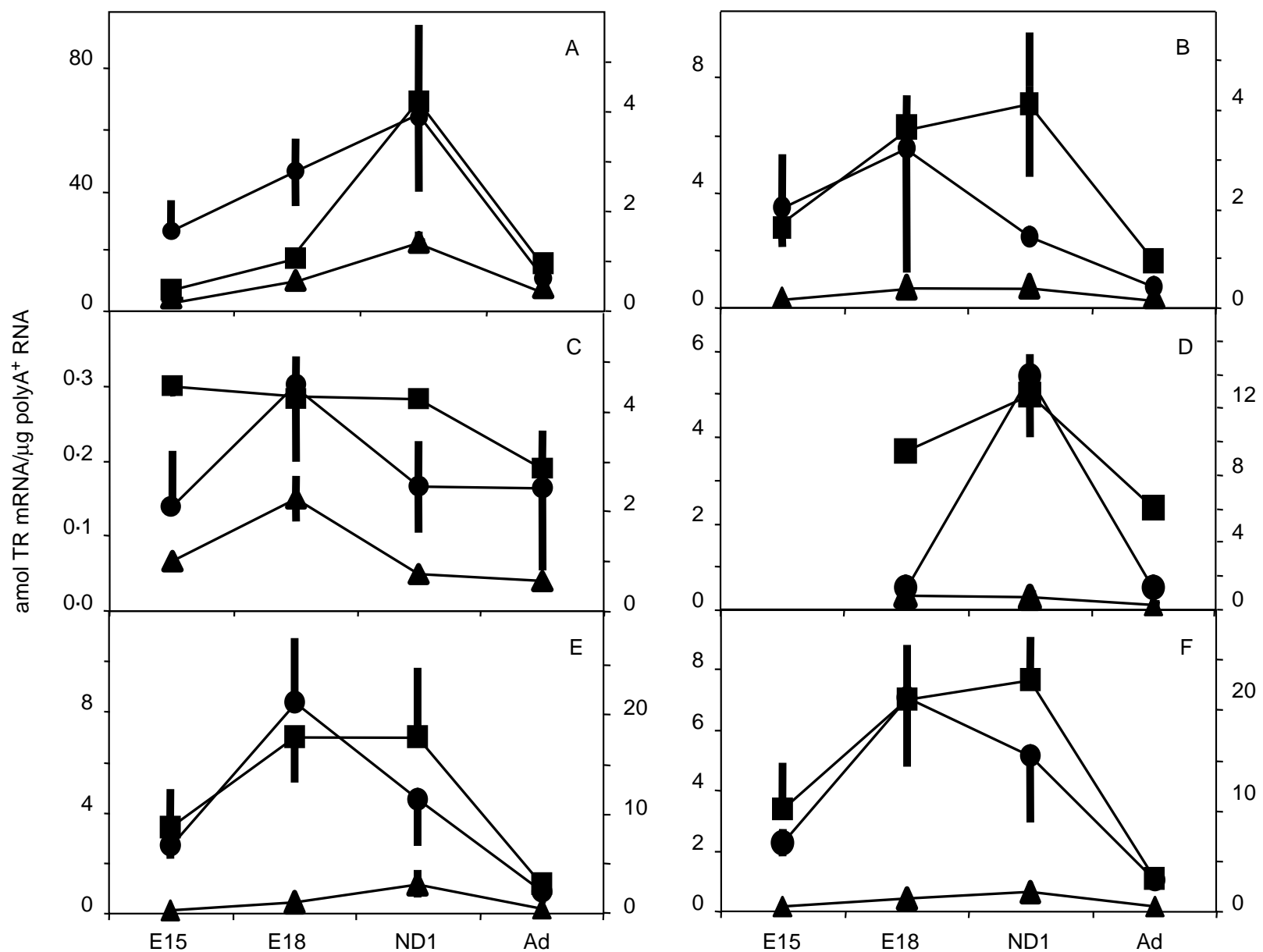

Figure 2 Quantification of thyroid hormone receptor mRNA levels during perinatal development. A, brain; B, lung; C, liver; D, kidney; E, small intestine; $F$, colon. TR $\alpha_{1}$ (triangles), TR $\alpha_{2}$ (squares), and $T R \beta_{1}$ (dots) mRNA concentrations are depicted \pm s.E.M. The age of the animals is indicated on the $X$-axis, while the concentration of the mRNAs is shown on the $Y$-axis $\left(l\right.$ eft, TR $\alpha_{1}(\bar{C}-F)$ and TR $\alpha_{2}$, and right, $\mathrm{TR} \alpha_{1}(\mathrm{~A}$ and $\mathrm{B})$ and $\mathrm{TR} \beta 1$ concentration). Note that the scales of the $Y$-axes differ in the respective panels.

glands, with the highest concentration in the posterior lobe (Fig. 4C and F). Both TR $\alpha$ isoforms only became detectable after birth in the anterior and middle lobes (Fig. 4A, B, D and E).

\section{Lung}

The pulmonary epithelium is initially surrounded by a conspicuous mass of mesenchyme. Expression of TR $\alpha$ mRNA in this mesenchyme was first observed at E13 and became pronounced at E15 (Fig. 5A). TR $\beta$ mRNA expression in the epithelium became more intense during the subsequent 'canalicular' phase of the lung development (E16-E18; Fig. 5B and D), when TR $\alpha$ mRNA expression remained distinctly present in the mesenchyme (Fig. 5C). Owing to the attenuation of the walls of the airways during the 'alveolar' phase of lung development ( $>$ E19), the complementary expression pattern of $\operatorname{TR} \alpha$ and $\operatorname{TR} \beta$ became more and more difficult to discern (Fig. 5E and F). TR $\beta$ mRNA remained present in the wall of the pulmonary arteries (arrows Fig. 5D and F) and TR $\alpha$ mRNA in the myocardium of the pulmonary veins (arrows Fig. 5C). $\mathrm{TR} \alpha_{2}$ mRNA levels were approx. tenfold higher than $\mathrm{TR} \alpha_{1}$ mRNA levels and peaked at E18 and P1 (Fig. 2B), indicating that the $\mathrm{TR} \alpha$ in situ hybridization signal actually represented $T R \alpha_{2}$ mRNA. The TR $\beta$ signal in the in situ hybridizations represented TR $\beta_{1}$, because no TR $\beta_{2}$ mRNA could be detected. TR $\beta_{1}$ mRNA levels peaked at E18 (Fig. 2B).

Western blot analysis revealed the presence of $\mathrm{TR} \alpha_{1}$ protein at $\mathrm{E} 17$ and a marked increase in the concentration by $\mathrm{P} 4$ (Fig. $3 \mathrm{~A}$ and $\mathrm{B}$ ). At the same time points, the intensity of the $\mathrm{TR} \alpha_{2}$-protein band was relatively weak and even appeared to decrease with development (Fig. 3D and E). TR $\beta_{1}$ protein levels were similar at E17 and P4 (Fig. 3G and H). Despite the positive western blots, we were not able to demonstrate 


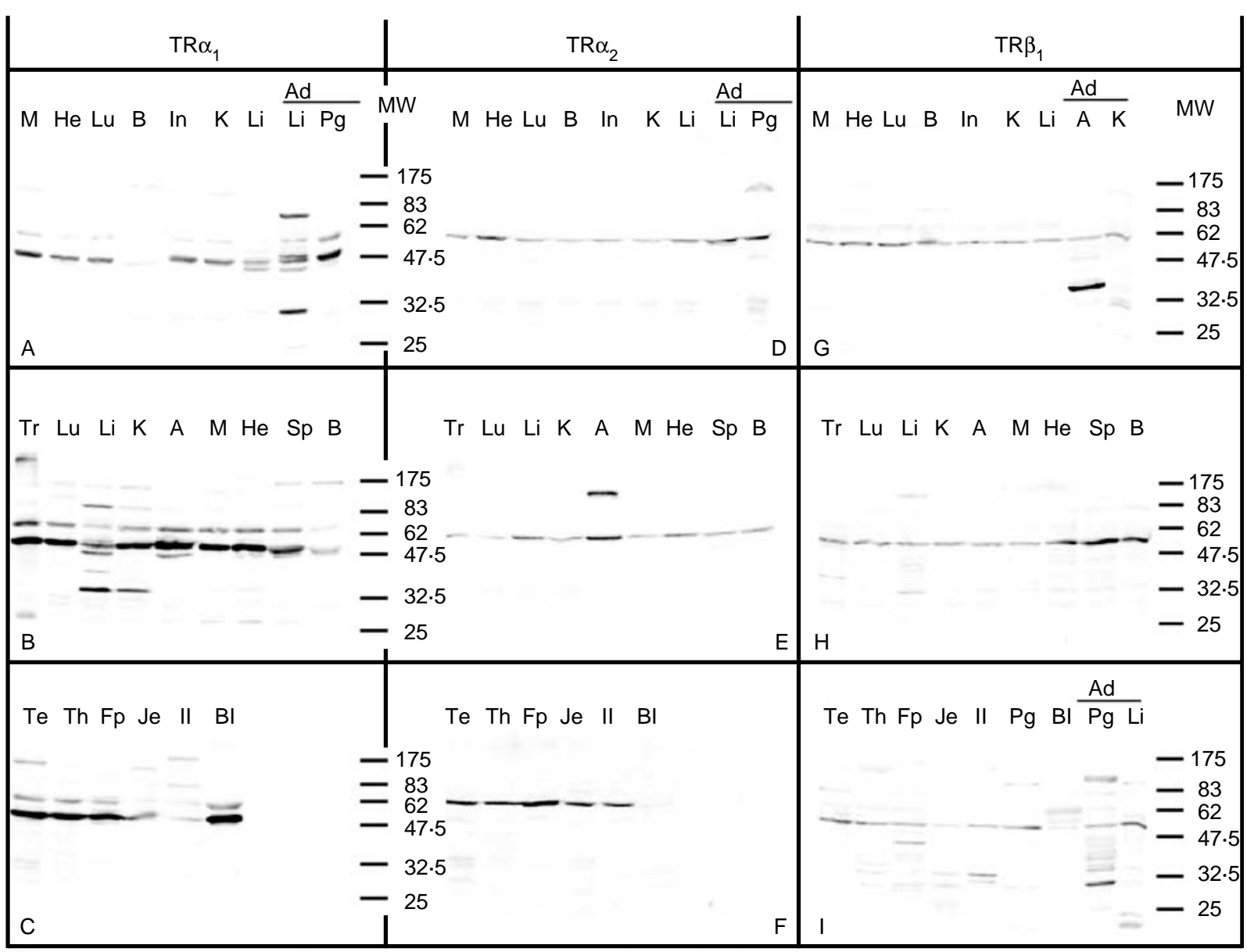

Figure 3 Western blot of thyroid hormone receptor protein levels during perinatal development. Representative example of three extracts assayed in triplicate. A-C, TR $\alpha_{1}$; D-F, TR $\alpha_{2}$; G-I, TR $\beta_{1}$; A, D and G: E17; B, C, E, F, H and I: P4. Ad, adult; MW, molecular weight. Organ abbreviations: A, adrenal gland; BI, bladder; B, brain; Fp, epididymal fat pad; He, heart; In, intestine; II, ileum; Je, jejunum; K, kidneys; Li, liver; Lu, lung; M, muscle; Pg, pituitary gland; Sp, spleen; Te, testis; Th, thyroid gland; Tr, trachea.

either $\mathrm{TR} \alpha_{1}$ or $\mathrm{TR} \alpha_{2}$ protein by immunohistochemistry (Fig. 5G, $\mathrm{H}, \mathrm{J}$ and $\mathrm{K}$ ), indicating that the proteins were present at low levels in many cells. $\operatorname{TR} \beta_{1}$ protein was predominantly expressed in lung epithelium (Fig. 5J and $\mathrm{L}$ ). The protein: mRNA ratio for $\mathrm{TR} \alpha_{1}$ increased in development, and remained more or less constant for $\mathrm{TR} \alpha_{2}$ and $\operatorname{TR} \beta_{1}$

\section{Liver}

Expression of TR $\alpha$ mRNA in the liver was first observed at E15 (Fig. 6A) and could be located in the stromal component, including the wall of the veins, from E17 onwards (Fig. 6C and E). Expression of TR $\beta$ mRNA was also observed at E15, declined during the next 2 days to undetectable levels, but reappeared in the parenchymal tissue at E19 (Fig. 6B, D and F). At E20, the complementary expression of TR $\alpha$ in the stromal and of TR $\beta$ in the parenchymal tissue had become very striking (Fig. $6 \mathrm{E}$ and $\mathrm{F}$ ). The concentration of $\mathrm{TR} \alpha_{1}$ and, in particular, $\mathrm{TR} \alpha_{2}$ mRNA, was very low when compared with other tissues during all ages investigated (Fig. 2C). As a result, the $\mathrm{TR} \alpha_{1}$ : $\mathrm{TR} \alpha_{2}$ ratio was the highest observed in any of the tissues investigated and was more than five times higher than that in the brain. TR $\beta_{1}$ mRNA levels peaked at E18 (Fig. 2C), whereas $\mathrm{TR} \beta_{2}$ mRNA levels were undetectable.

In liver extracts, the $\mathrm{TR} \alpha_{1}$ antibody detected not only a band at the expected size $(47 \mathrm{kDa})$ but also bands at higher and lower $M_{r} \mathrm{~s}$. TR $\alpha_{1}$ levels increased between E17 and $\mathrm{P} 4$, when concentrations reached adult values (Fig. 3A and $\mathrm{B}$ ), whereas the $\mathrm{TR} \alpha_{2}$ protein did not change (Fig. 3D and E). Similarly, the $57 \mathrm{kDa}$ TR $\beta_{1}$ band did not change in development, but bands of 30 and $110 \mathrm{kDa}$ became increasingly prominent (Fig. 3G and $\mathrm{H}$ ). Immunohistochemical staining revealed weak staining of $\mathrm{TR} \alpha_{1}$ protein in parenchymal cells surrounding the central veins, but after birth only (Fig. 6G 


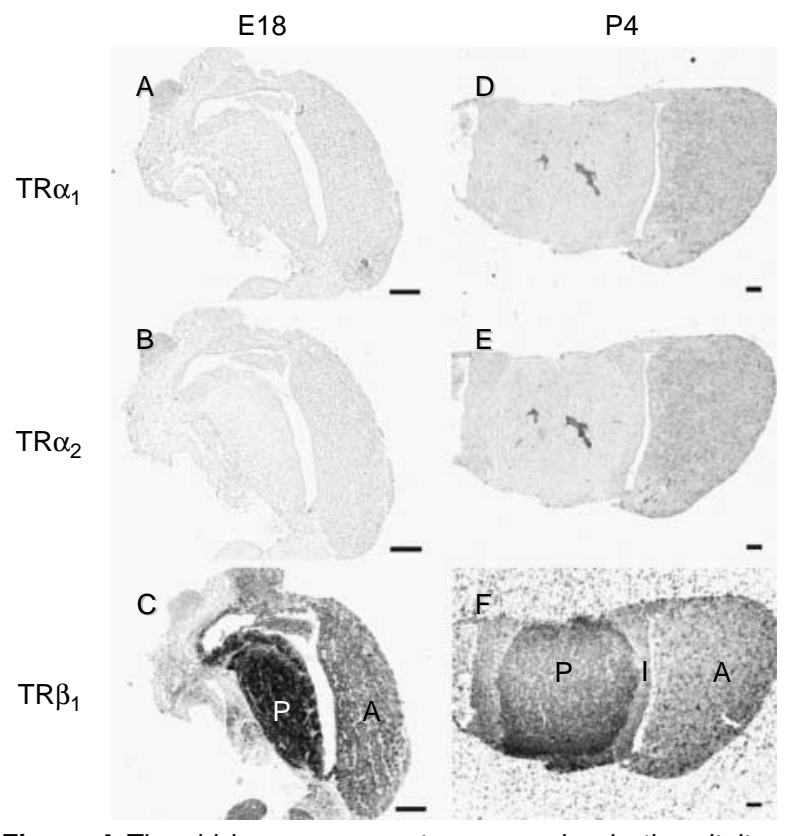

Figure 4 Thyroid hormone receptor expression in the pituitary gland. $T R \alpha_{1}$ and $T R \alpha_{2}$ proteins are not detectable in the $E 18$ pituitary ( $A$ and $B$ ) and begin to accumulate postnatally (P4) in the anterior lobe ( $D$ and $E)$. In contrast, $T R \beta_{1}$ protein was highly expressed at $\mathrm{E} 18(\mathrm{C})$ and $\mathrm{P} 4(\mathrm{~F})$, in particular, in the middle lobe. $\mathrm{A}$, anterior; I, intermediate; and $\mathrm{P}$, posterior lobe of pituitary. Bar, $100 \mu \mathrm{m}$.

and J; cf. (Zandieh-Doulabi et al. 2003), whereas TR $\alpha_{2}$ protein had then become detectable in isolated liver cells (Fig. $6 \mathrm{H}$ and $\mathrm{K}$ ). In fetal rat liver, TR $\beta_{1}$ protein was observed faintly in the parenchyma of the liver (Fig. 6I). After birth, expression had become much stronger in the hepatocytes surrounding the central veins (Fig. 6L; cf. (Zandieh Doulabi et al. 2002)). The protein: mRNA ratios for $\mathrm{TR} \alpha_{1}, \mathrm{TR} \alpha_{2}$, and $\mathrm{TR} \beta_{1}$ did not change appreciably with development.

\section{Kidney}

The development of the definitive kidney is characterized by the penetration of the ureteric bud into the metanephric mass. The metanephric tubules expressed TR $\beta$ mRNA (Fig. 7B, D and F), whereas the ureteric buds and surrounding mesenchyme expressed TR $\alpha$ mRNA (Fig. 7A, C and E). TR $\alpha_{2}$ mRNA levels were more than ten times higher than $\mathrm{TR} \alpha_{1}$ levels (Fig. 2D). Both $\mathrm{TR} \alpha_{1}$ and $\mathrm{TR} \alpha_{2}$ mRNA concentrations peaked perinatally, whereas TR $\beta_{1}$ mRNA peaked just after birth. TR $\beta_{2}$ mRNA was undetectable.

$\mathrm{TR} \alpha$ protein levels increased perinatally, with a band of $30 \mathrm{kDa}$, which is also present in liver extracts, becoming more prominent with age (Fig. 3A and $\mathrm{B}$ ). At E18, TR $\alpha_{1}$ protein was weakly present in the nephric tubules (Fig. 7G), but had disappeared at P4 (Fig. 7J).
$\mathrm{TR} \alpha_{2}$ protein was not detectable in any cell type in the kidney (Fig. $7 \mathrm{H}$ and $\mathrm{K}$ ). TR $\beta_{1}$ protein was detected in the glomeruli and tubules at E18 (Fig. 7I). After birth, the glomeruli were no longer positive (Fig. 7L). The protein:mRNA ratio for $\mathrm{TR} \alpha_{1}$ and $\mathrm{TR} \alpha_{2}$ did not change appreciably in development. If, however, the $30 \mathrm{kDa}$ band is a proper $\mathrm{TR} \alpha_{1}$ gene product, the protein: mRNA ratio for $\mathrm{TR} \alpha_{1}$ does increase with development. The protein:mRNA ratio for $\mathrm{TR} \beta_{1}$ declined with development, but in the adult, a $30 \mathrm{kDa}$ band that was also seen in liver, had become very prominent. If this is a bona fide $\operatorname{TR} \beta_{1}$ gene product, the ratio is substantially higher in the adult.

\section{Adrenals}

TR $\alpha$ mRNA, which was still found in the entire adrenal at E16 (Fig. 7A), had become confined to dispersed islands of cells in the medulla and the capsule at E18 (Fig. 7C). TR $\beta$ mRNA levels were low and confined to the capsule (Fig. 7B and D). PCR analysis was not performed. Western blot analysis showed prominent bands for both $\mathrm{TR} \alpha_{1}$ and $\mathrm{TR} \alpha_{2}$ after birth (Fig. 3B and E). The $\mathrm{TR} \alpha_{2}$ antibody produced an additional $100 \mathrm{kDa}$ band. This band was also observed in human (not shown), but not in rat pituitary gland. Only one band was observed for $\mathrm{TR} \beta_{1}$ protein (Fig. 3F). The $\mathrm{TR} \alpha_{1}$ protein was diffusely distributed in the adrenal at E18 (Fig. 8A), but had become confined to the adrenal medulla at P4 (Fig. 8D). The distribution of $\mathrm{TR} \alpha_{2}$ protein was confined to well-defined islets of cells at E18 (Fig. 8B) and to the medulla after birth (Fig. 8E). The $\mathrm{TR} \beta_{1}$ protein was diffusely distributed in the adrenal tissue and capsule at E18 (Fig. 8C), but became localized to the adrenal cortex after birth (Fig. 8F). The morphological data indicate that the TR $\alpha$ mRNA in the adrenal capsule does not generate detectable protein. In contrast, the low abundance of TR $\beta$ mRNA and the readily detectable $\operatorname{TR} \beta_{1}$ protein in sections indicate a high protein:mRNA ratio.

\section{Intestines}

The epithelial layer of the intestines (Fig. 9A-F) and the parenchymal cells of the pancreas (Fig. 9C and D) co-expressed TR $\alpha$ and TR $\beta$ mRNA from E16 onward (Fig. 9A-F). Between E18 and E20, both TR $\alpha$ and TR $\beta$ mRNAs became confined to the crypts. TR $\alpha_{1}, \mathrm{TR} \alpha_{2}$, and TR $\beta_{1}$ mRNA levels followed a similar developmental pattern and peaked perinatally (Fig. 2E and F).

Western blotting showed that $\mathrm{TR} \alpha_{1}$ protein levels decreased between 5 days before birth and 4 days after birth (Fig. 3A and C). The opposite was true for $\mathrm{TR} \alpha_{2}$ protein (Fig. 3D and F). Relatively low levels of TR $\beta_{1}$ protein were found both pre- and postnatally (Fig. 3G and I). The $\mathrm{TR} \alpha_{1}$ antiserum generated staining at the 


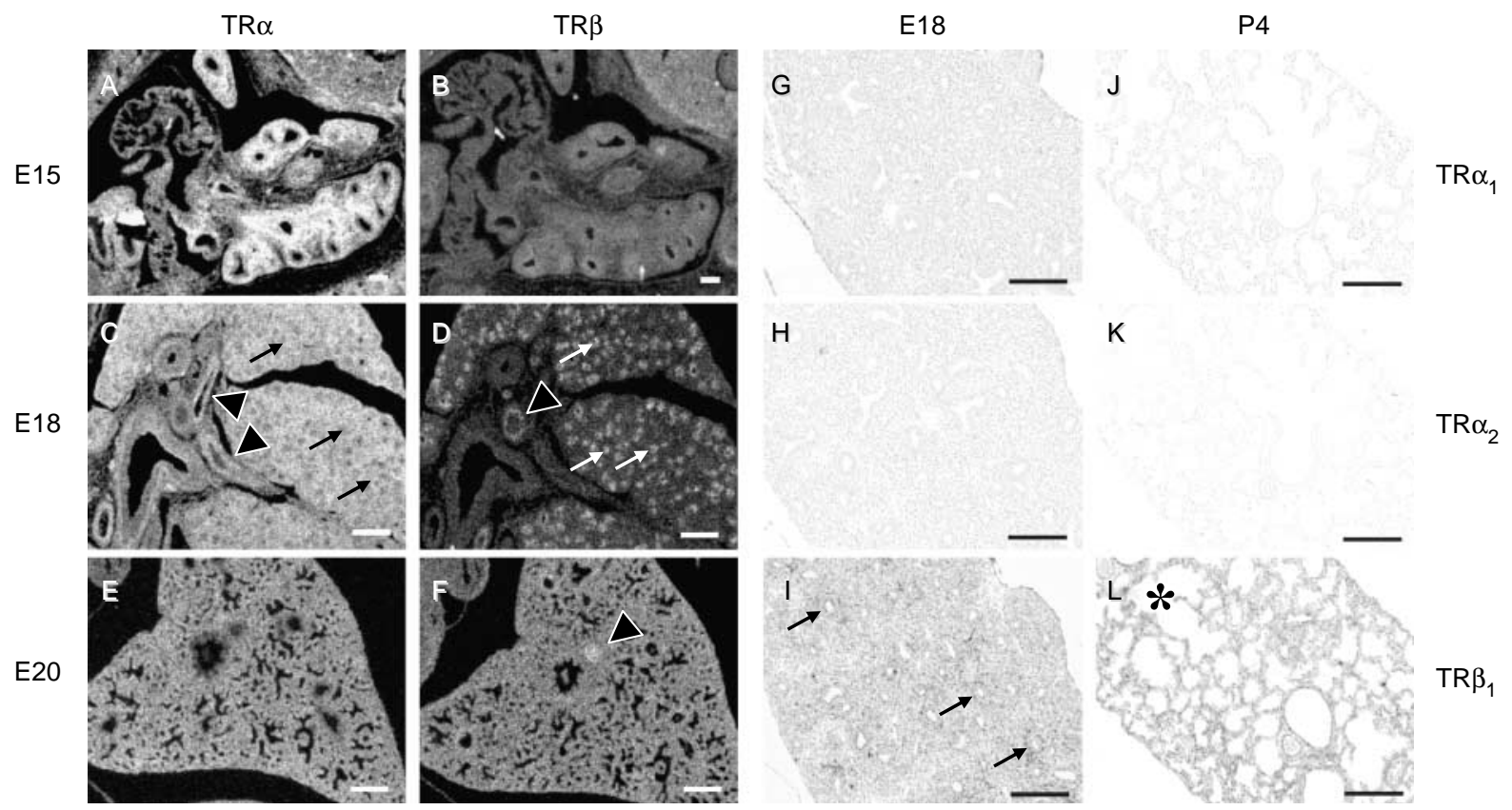

Figure 5 Thyroid hormone receptor expression in perinatal lung. TR $\alpha$ mRNA was prominently present in the lung mesenchyme at E15 (A) and E18 (C). TR $\beta$ mRNA in the pulmonary epithelium is visible at E15 (B) and pronounced at E18 (D). Note the complementarity of TR $\alpha$ and TR $\beta$ mRNA expression (C and D). Thereafter ( $E$ and F: E20), the complementary distribution was no longer demonstrable. The pulmonary vein is identifiable by its expression of $\operatorname{TR} \alpha(C)$, whereas the pulmonary artery is characterized by TR $\beta$ expression in its myocardial wall (D and F; arrowheads). TR $\alpha_{1}(G$ and $J)$ and TR $\alpha_{2}$ proteins (H and K) were undetectable at E18 $(\mathrm{G}$ and $\mathrm{H})$ and $\mathrm{P} 4(\mathrm{~J}$ and $\mathrm{K})$. TR $\beta_{1}$ protein was largely confined to the epithelium and detectable at both $\mathrm{E} 18(\mathrm{I})$ and P4 (L). Arrows, terminal bronchioli ('canaliculi'); asterisk, terminal bronchioli and alveoli. Bar, $100 \mu \mathrm{m}$.

apical surface of the enterocytes at E18, but not at P4 (Fig. 9G and J). TR $\alpha_{2}$ protein could not be detected (Fig. $9 \mathrm{H}$ and $\mathrm{K}$ ). In contrast, strong staining for TR $\beta_{1}$ protein was observed in the smooth-muscle layer of the intestine at E18 (Fig. 9I) and P4 (Fig. 9L), as opposed to a relatively weak staining in the mucosa. The $\mathrm{TR} \alpha$ mRNAs, therefore, generated very little protein in the epithelium. The protein:mRNA ratio for $\mathrm{TR} \beta_{1}$ in the epithelium was also low. At the same time, high levels of $\mathrm{TR} \beta_{1}$ protein were present in the smooth muscle layer, where the corresponding mRNA was barely detectable.

\section{Comparison of TR protein in organs}

We demonstrated the presence of $\mathrm{TR} \alpha_{1}$ and $\mathrm{TR} \alpha_{2}$ proteins on western blots of several other organs (Fig. 3, Table 1). Quantification showed that the concentrations of $\mathrm{TR} \alpha_{1}$ protein in lung, muscle, heart, kidney, adrenals, pituitary gland, spinal cord, testis, and fat pad were similar, that in brain, liver, and small intestine were approximately threefold lower, and that in trachea and red blood cells were twofold higher than average. Average concentrations of $\mathrm{TR} \alpha_{2}$ were found in liver, small intestine, and kidney, a very low concentration in red blood cells, approximately twofold lower than average concentrations in lung, trachea, muscle, heart, spinal cord, and brain, and twofold higher than average in the fat pad, testis, and adrenals. The resulting $\mathrm{TR} \alpha_{1}: \mathrm{TR} \alpha_{2}$ ratio, a parameter for tissue thyroid hormone responsiveness, was 3- to 10-fold lower than average in brain, liver, prenatal heart, lung, postnatal small intestine, adrenals, and fat pad; 2- to 10-fold higher than average in postnatal lung, trachea, muscle, and pituitary gland, and extremely high for blood. The $\mathrm{TR} \alpha_{1}: \mathrm{TR} \alpha_{2}$ ratio declined with the development in liver and small intestine, and increased in lung, muscle, heart, and brain. The TR $\beta_{1}$ concentration was remarkably similar in all analyzed organs before birth and, after birth, relatively low in muscle, bone, fat pad, small intestine, and red blood cells, and relatively high in brain and spinal cord.

\section{Comparison of the protein:mRNA ratio between organs}

Protein synthesis is determined by the corresponding steady-state mRNA level and translational efficiency, whereas the steady-state protein level is determined by its synthesis (translation) and degradation. If we assume that no major changes occurred in the tissue concentration of polyA ${ }^{+}$mRNA or total protein with time and that TR mRNAs are not sequestered from 

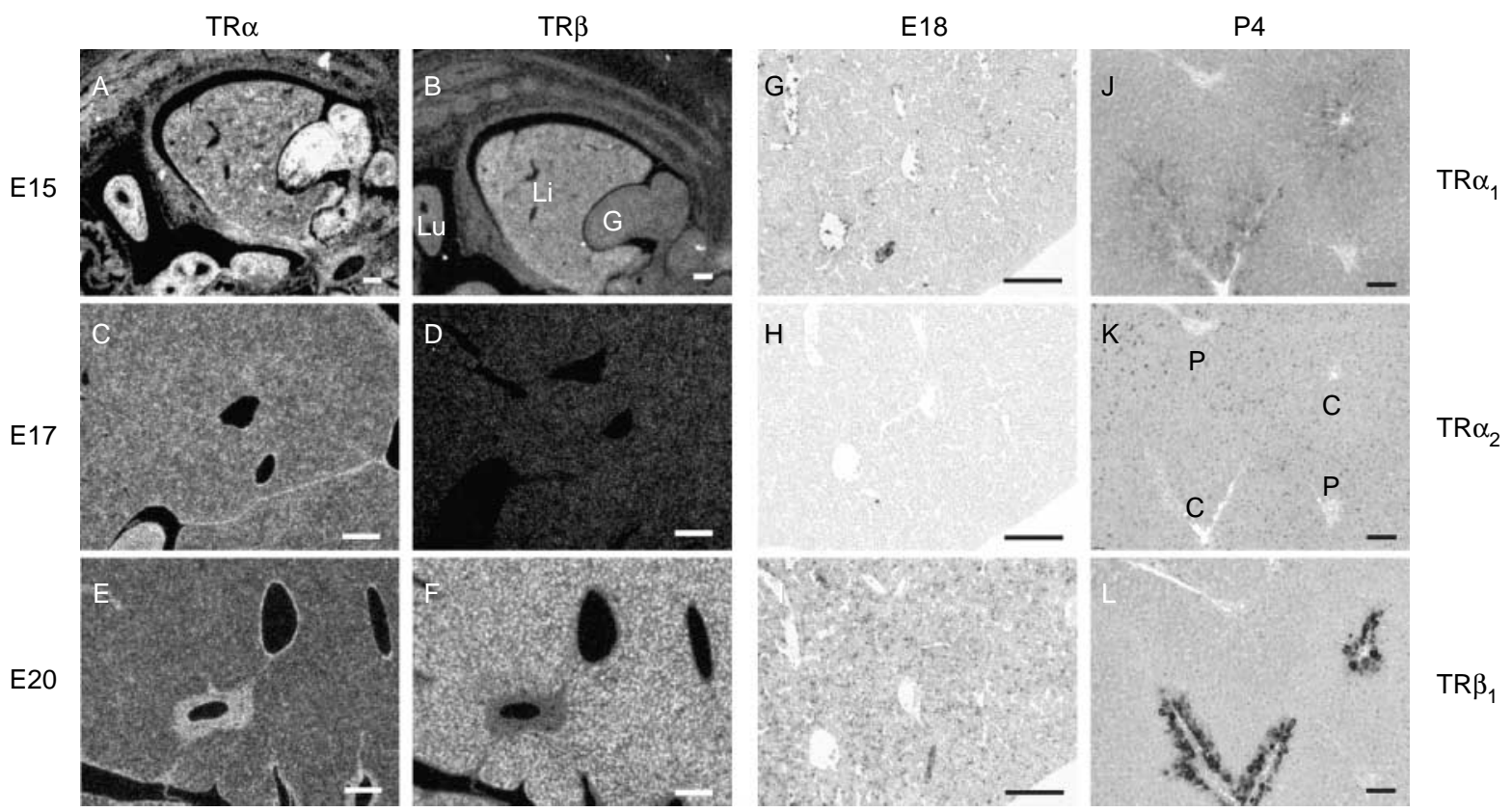

Figure 6 Thyroid hormone receptor expression in perinatal liver. TR $\alpha$ mRNA was readily detectable in prenatal liver mesenchyme (A, E15; C, E17; E, E20). Expression declined in liver stroma, but became more prominent in the developing perivascular mesenchyme. TR $\beta$ mRNA was also readily detectable at $E 15(B)$, temporarily declined (D; E17), but had reappeared in the hepatocytes at E20 (F). Note the complementarities of TR $\alpha$ and TR $\beta$ mRNA expressions (E and F). At E18 (G), TR $\alpha_{1}$ protein concentration was barely detectable, but at P4 $(\mathrm{J})$, it had accumulated in the pericentral hepatocytes. Similarly, TR $\alpha_{2}$ protein was undetectable before birth $(\mathrm{H}, \mathrm{E} 18)$, but was observed in isolated liver cells after birth (K, P4). TR $\beta_{1}$ protein was present in most hepatocytes before birth (I), but had become confined to the pericentral hepatocytes by P4 (L). Li, liver; Lu, lung; G, gonad; P, portal vein; C, central vein. Bar, $100 \mu \mathrm{m}$.

the translational machinery at a specific time point, protein:mRNA ratios inform us about the presence of a posttranscriptional level of regulation of gene expression (cf. Table 1). During lung development, the protein:mRNA ratio of $\mathrm{TR} \alpha_{1}$ increased, but the ratios of $\mathrm{TR} \alpha_{2}$ and $\mathrm{TR} \beta_{1}$ remained more or less constant. Similarly, the protein:mRNA ratios for $\mathrm{TR} \alpha_{1}$, $\mathrm{TR} \alpha_{2}$, and $\mathrm{TR} \beta_{1}$ did not change appreciably with liver and kidney development. During intestinal development, the TR $\alpha$ and TR $\beta$ mRNAs generated very little protein in the epithelium, but the reverse was true for the smooth muscle layer, where a barely detectable $\mathrm{TR} \beta_{1}$ mRNA generated a high concentration of protein. In the brain, the protein:mRNA ratio was very low for $\mathrm{TR} \alpha_{1}$ and $\mathrm{TR} \alpha_{2}$, whereas that for $\mathrm{TR} \beta_{1}$ was highest.

\section{Discussion}

Despite the detailed insights into the molecular mechanisms underlying the thyroid hormone- and TR-dependent modulation of gene expression that are now available (Cheng 2000, Zhang \& Lazar 2000, Baxter et al. 2001, Yen 2001, O'Shea \& Williams 2002,
Chassande 2003, Flamant \& Samarut 2003) and the undisputed role of thyroid hormone in organogenesis (Oppenheimer \& Schwartz 1997, Tata 1999), the mechanistic aspects of thyroid hormone action in development are still debated. Nevertheless, it is likely that epithelial-mesenchymal interactions play a role, because mesenchymal cells are thought to be primary determinants of epithelial cell fate during organogenesis (Brard 1990). Using in situ hybridization and immunohistochemistry as visualization techniques, and RT-PCR and western blotting as quantification techniques, we indeed observed a highly specific distribution pattern of the TR isoforms that appears to support such a mechanism of action for thyroid hormones. Expression of the $\mathrm{TR} \alpha$ isoform was observed in the mesenchymal tissues and expression of the TR $\beta$ isoform in the epithelial tissues of lung, liver, kidney, sensory system of the inner ear, and bone. As far as we know, this generalization has not been made so far. However, this generalization did not apply to the central nervous system and the intestine. In addition, the relation was obscured by an extensive posttranscriptional regulation of the expression of the TRs, with differences between organs and between different developmental stages of the same organ 


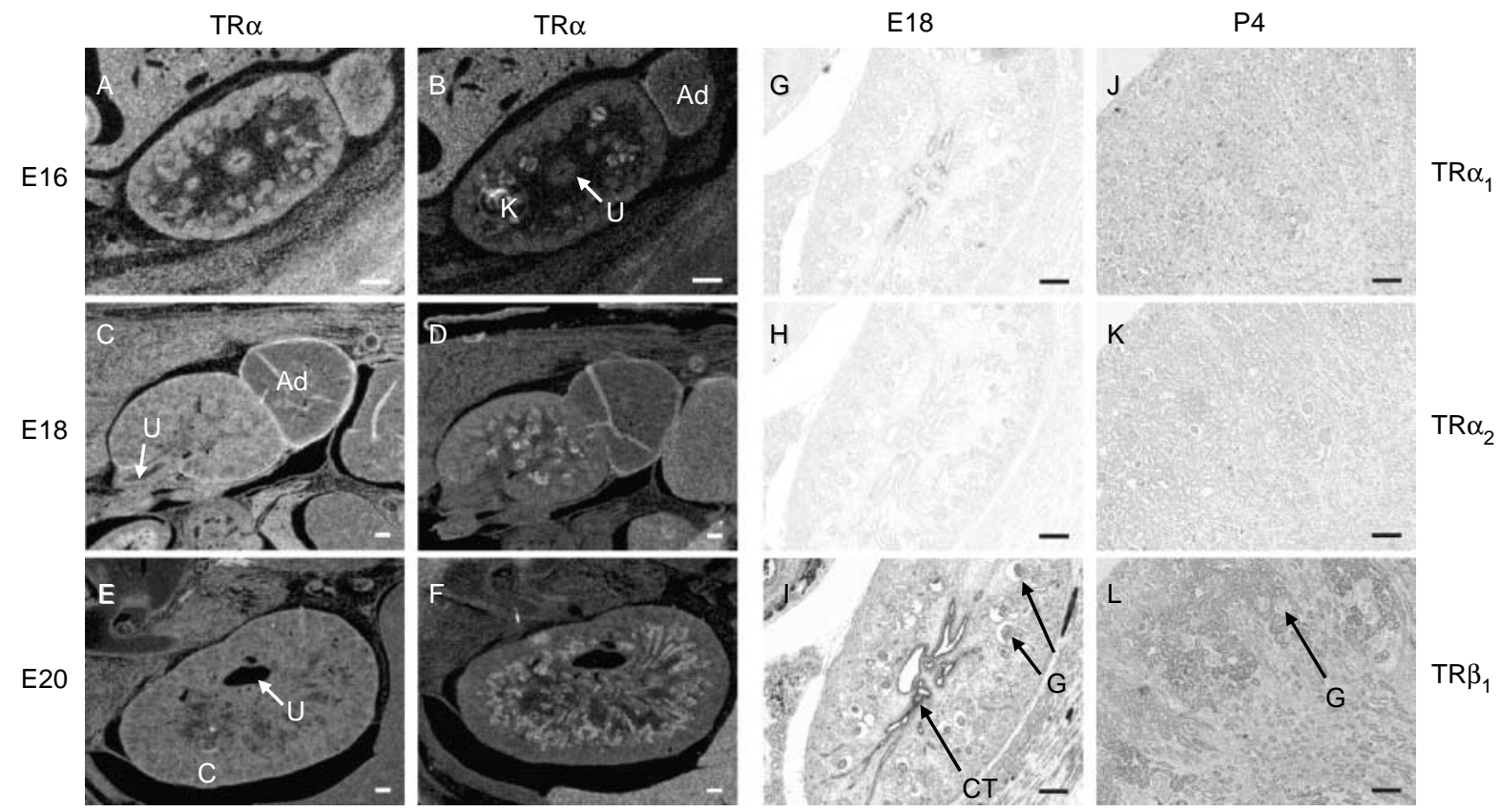

Figure 7 Thyroid hormone receptor expression in perinatal kidney. TR $\beta$ mRNA was present in the developing nephrons from E16 onwards (B, E16; D, E18; F, E20). TR $\alpha$ mRNA was present in the surrounding mesenchyme, but declined with development (A, E16; C, E18; E, E20). TR $\alpha_{1}$ protein was seen in the collecting tubules at E18 (G), but had disappeared at P4 (J). TR $\alpha_{2}$ protein was not detectable at either $\mathrm{E} 18(\mathrm{H})$ or $\mathrm{P} 4(\mathrm{~K})$. At E18, TR $\beta_{1}$ protein was present in the glomeruli and, more abundantly, in the collecting tubules (I). After birth, TR $\beta_{1}$ protein had disappeared from the glomeruli (L). At E16, TR $\alpha$ mRNA was weakly expressed in the entire adrenal $(A)$, but had become largely confined to the capsule at E18 $(C)$. A weak staining for TR $\beta$ mRNA was seen in the capsule of the adrenals (B and D). Ad, adrenal; K, kidney with U, ureter; C, cortex; G, glomerulus; and CT, collecting tubules. Bar, $100 \mu \mathrm{m}$.

(cf. also (Strait et al. 1990, Lane et al. 1991, Rodd et al. 1992, Schwartz et al. 1992, Weiss et al. 1998)). In this respect, it is of interest that the protein:mRNA ratios that we derived for brain, liver, and kidney resemble those derived by Oppenheimer and Schwartz (Oppenheimer \& Schwartz 1997) with respect to the TR $\alpha_{1}$, but, in contrast to their findings, we concluded that the $\mathrm{TR} \beta_{1}$ protein:mRNA ratio is higher in brain than in liver.

The complementary expression pattern of TR $\alpha$ and $\operatorname{TR} \beta$ was most pronounced in developing lung, liver, and kidney, that is, in organs with distinct epithelial and mesenchymal components. Since most epithelia cannot differentiate when separated from their associated mesenchyme (Birchmeier \& Birchmeier 1993), it is thought that epithelial differentiation is under control of its underlying mesenchyme. The respective expression patterns were much more pronounced at the mRNA than at the protein level, implying important posttranscriptional control mechanisms. Although both mRNA and protein levels in the organs mentioned reached maximal levels perinatally, it is of interest that for those organs, for which paired samples were available, tissue $\operatorname{TR} \alpha_{2}$ and $\operatorname{TR} \beta_{1}$ protein peaked at 5 days before birth. In contrast, $\operatorname{TR} \alpha_{1}$ protein follows a similar time course as circulating thyroid hormones
(Dubois \& Dussault 1977) to reach its highest level after birth. This latter temporal association is in line with the finding that unliganded $T R \alpha 1$ is detrimental to postnatal development (Chassande 2003). Our data, therefore, suggest that an initiating, (unliganded) TR $\beta$ mediated role of the epithelium induces a TR $\alpha$ mediated response of the mesenchyme.

On the other hand, extensive co-expression of TR $\alpha$ and TR $\beta$ was observed in the developing brain and intestinal epithelium. Despite the high level of $\mathrm{TR} \alpha_{1}$ and particularly $\mathrm{TR} \alpha_{2}$ mRNA in these organs, $\mathrm{TR} \alpha_{1}$ protein levels were much lower, and $\mathrm{TR} \alpha_{2}$ protein levels were similar to those in the other organs investigated. In other words, organs with co-expression of $\operatorname{TR} \alpha$ and $\mathrm{TR} \beta$ in the same cells seem to be characterized by a very low TR protein:mRNA ratio in the perinatal period. Thus, the protein:mRNA ratio for $\mathrm{TR} \alpha_{1}$ was more than tenfold lower and that of $\mathrm{TR} \alpha_{2} 15$ - to 50-fold lower in perinatal brain than in perinatal liver, lung, or kidney. In contrast, the protein:mRNA ratio for $\mathrm{TR} \beta_{1}$ was similar in these four organs in this period, but was very low in intestinal epithelium, especially before birth. This implies that in organs with co-expression of $\mathrm{TR} \alpha$ and TR $\beta$, the translational efficiency of one of the TR mRNAs is much lower, and/or that the turnover of TR protein is much higher than that in cells without 


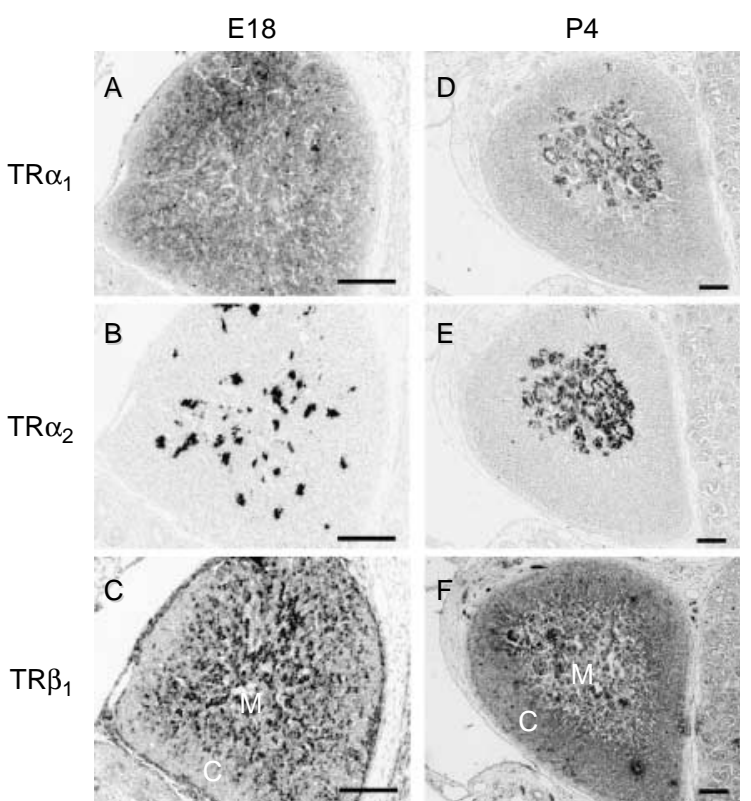

Figure 8 Thyroid hormone receptor expression in the adrenal glands. $T R \alpha_{1}$ protein was present in most parenchymal cells of the adrenal at E18 (A), but had become confined to the adrenal medulla at P4 (D). TR $\alpha_{2}$ protein was confined to islets of cells at E18 (B) and to the adrenal medulla after birth (E). TR $\beta_{1}$ protein was seen to be present in the adrenal and its capsule at E18 (C), but became concentrated in the adrenal cortex after birth (F). C, cortex and $\mathrm{M}$, medulla of adrenal gland. Bar, $100 \mu \mathrm{m}$. co-expression. These data indicate that the TR-dependent regulatory cascades function differently in those organs in which the TR $\alpha$ and TRß genes are characterized by a complementary expression pattern and those in which they are co-expressed. Intriguingly, these posttranscriptional regulatory mechanisms, therefore, largely annul the apparent dominance of $\mathrm{TR} \alpha_{2}$ expression in the central nervous system and that of $\operatorname{TR} \beta_{1}$ expression in the intestine.

We observed an apparent discrepancy between the relatively weak staining of $\mathrm{TR} \alpha$ proteins in histological sections of all organs except the adrenal, and their strong presence, in particularly $\mathrm{TR} \alpha_{1}$, on western blots. Although one explanation would be that the TRas were not well accessible in the tissue sections of most organs, the use of a denaturing rather than a cross-linking fixative and absence of an effect of preprocessing the sections with antigen-retrieval techniques shows that, more likely, they are distributed over many more cells, hence that the cellular concentration remains too low to strongly stain these tissues. This interpretation suggests a more homogeneous distribution of TRas than $\mathrm{TR} \beta_{1}$ in brain, lung, bone, and kidney. In agreement, the $\mathrm{TR} \alpha_{1}$ and $\mathrm{TR} \alpha_{2}$ proteins stained homogeneously in the anterior pituitary gland (Fig. 4), while the $\mathrm{TR} \alpha_{1}$ protein had a much wider pericentral expression pattern in the liver than the
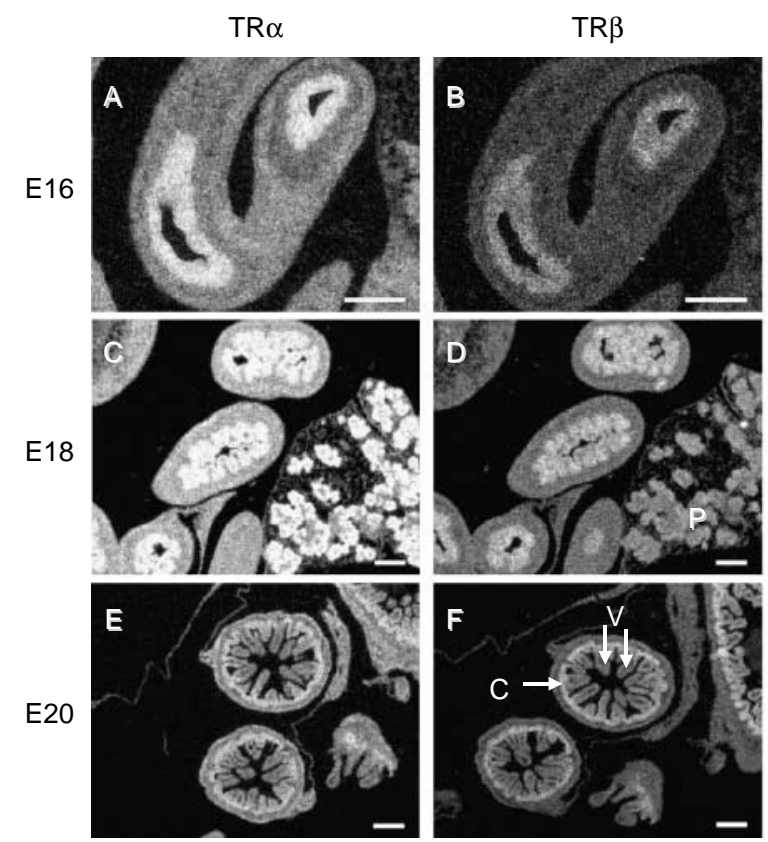

E18
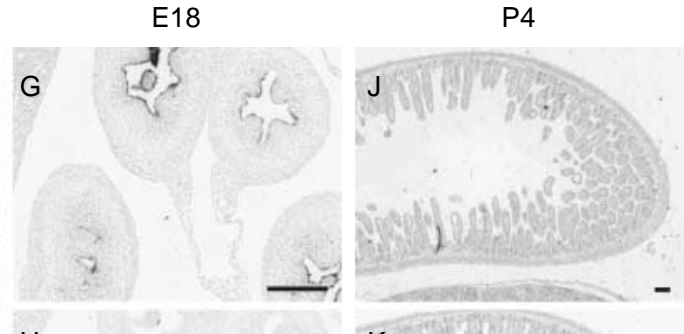

$\mathrm{TR} \alpha_{1}$
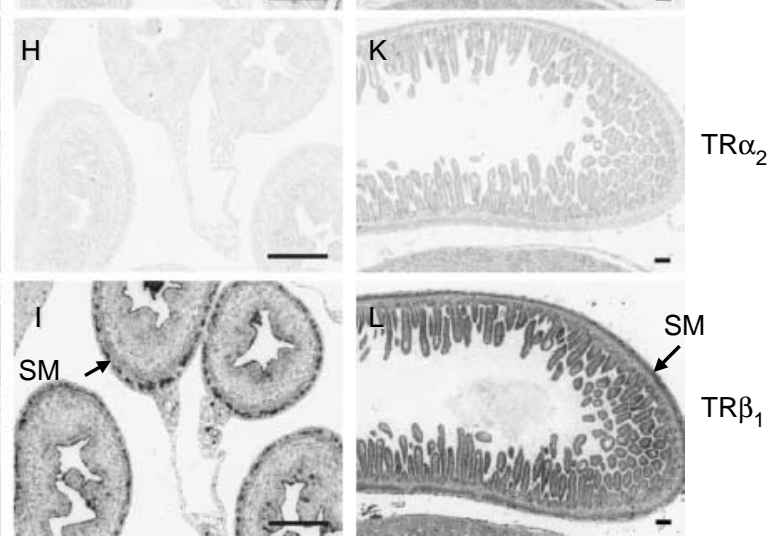

Figure 9 Thyroid hormone receptor expression in perinatal intestine. Note that TR $\alpha$ and TR $\beta$ mRNAs are co-expressed in the epithelium of the intestines at E16 (A and B), E18 (C and D), and E20 (E and F). From E18 onwards, both mRNAs became concentrated in the crypts. Also note the expressions of TR $\alpha$ and TR $\beta$ mRNA in the pancreatic epithelium (C and D). TR $\alpha_{1}$ protein staining was present in the apical part of the villar epithelium before $(\mathrm{G})$, but not after birth $(\mathrm{J})$. TR $\alpha_{2}$ protein was not detectable $(\mathrm{H}$ and $\mathrm{K}) . \mathrm{TR} \beta_{1}$ protein was seen predominantly in the smooth muscle layer and to a lesser extent in the epithelium of the intestine at E18 (I), and equally at both the locations after birth (L). C, crypt; V, villus; P, pancreas; SM, smooth-muscle layer. Bar, $100 \mu \mathrm{m}$. 
TR $\beta_{1}$ protein (Fig. 6; cf. also Zandieh Doulabi et al. 2002, 2003).

We detected $8 \cdot 9 \pm 2 \cdot 4$ amol TR $\beta_{2}$ mRNA in adult rat pituitary gland, but were unable to detect this TR $\beta$ isoform outside the pituitary, implying that $\mathrm{TR} \beta_{2}$ mRNA concentrations were more than 1000-fold lower. Nevertheless, we detected abundant staining in many organs with four rabbit antisera that were raised against a TR $\beta_{2}$-specific oligopeptide (data not shown). In the pituitary, staining was most pronounced in the intermediate lobe of the pituitary, as was reported earlier ( $\mathrm{Li} \&$ Boyages 1997). The putative $\mathrm{TR} \beta_{2}$ protein was $47 \mathrm{kDa}$, i.e., $11 \mathrm{kDa}$ less than predicted by the reported open reading frame (Hodin et al. 1989). Although the size of this protein corresponds with the $\mathrm{TR} \beta_{3}$ isoform (Williams 2000), the oligopeptide used for immunization is not present in $\mathrm{TR} \beta_{3}$. Possibly, $\mathrm{TR} \beta_{2}$ uses a more downstream translation initiation site (cf. (Wood et al. 1994)). The $\mathrm{pI}$ of the putative $\operatorname{TR} \beta_{2}$ protein was $7 \cdot 6$ in liver (corresponding with that of the unmodified $\mathrm{TR} \beta_{2}$ protein) and 5.0 in the pituitary gland. Extremely low cellular levels of TR $\beta_{2}$ mRNA in association with easily detectable $\mathrm{TR} \beta_{2}$ protein levels outside the pituitary gland were reported before (Lechan et al. 1993, Schwartz et al. 1994, Ercan-Fang et al. 1996, Oppenheimer \& Schwartz 1997).

Presently, gene targeting is one of the most powerful approaches to establish causal relations between gene expression and phenotype. The analysis of single and compound mutations of the Thra and Thrb loci has revealed that $\mathrm{TR} \alpha_{1}$ and $\mathrm{TR} \beta_{1}$ cooperate and can partially substitute for each other, and that the consequences of thyroid hormone deficiency differ from those of TR deficiency (O'Shea \& Williams 2002). $\mathrm{TR} \beta_{1}$ expression appears to be preferentially associated with the development of the cochlea and liver gene expression (Forrest et al. 1996, Weiss et al. 1998; cf. Figs 1 and 6), whereas $\operatorname{TR} \beta_{2}$ appears to be responsible for the development and maintenance of the hypothalamic-pituitary axis (Abel et al. 1999). As suggested by the pronounced phenotype of hypothyroid neonates, unoccupied TR $\beta$ s can interfere with normal development as well (Hashimoto et al. 2001). $\mathrm{TR} \alpha_{1}$ expression appears to be more closely associated with intestinal, cardiac, and bone development (Wikstrom et al. 1998, Plateroti et al. 1999, 2001). In agreement with our immunohistochemical data (cf. Figs 4 and 6 with Fig. 9), the effects of TR $\alpha$ deficiency become evident at weaning, that is, substantially later than those of TR $\beta$ deficiency. However, the expression and function of $\mathrm{TR} \alpha_{1}$ is materially complicated by the other products of the Thra locus, TR $\alpha 2$, and the TR $\Delta \alpha$ isoforms (O'Shea \& Williams 2002, Flamant \& Samarut 2003). Thus, $\mathrm{TR} \alpha_{1}$ deficiency differs from $\mathrm{TR} \alpha_{1 / 2}$ deficiency in the more severe phenotype of the latter, with hypothyroidism, runting, and maturational delays in bone and intestinal development that become manifest at weaning (Fraichard et al. 1997). In contrast, $\mathrm{TR} \alpha^{0 / 0}$ mice that lack all products from the Thra locus, including TR $\Delta \alpha$, have a milder phenotype than $\mathrm{TR} \alpha_{1 / 2^{-}}$ deficient mice (Macchia et al. 2001), due to the absence of the effects of TR $\Delta \alpha$ (Plateroti et al. 2001). Irrespective of these complexities, our study has shown that the developmental appearance of the respective TR proteins corresponds nicely with the phenotypes of mutations of the corresponding genes.

\section{Acknowledgements}

The authors declare that there is no conflict of interest that would prejudice the impartiality of this scientific work.

\section{References}

Abel ED, Boers ME, Pazos-Moura C, Moura E, Kaulbach H, Zakaria M, Lowell B, Radovick S, Liberman MC \& Wondisford F 1999 Divergent roles for thyroid hormone receptor $\beta$ isoforms in the endocrine axis and auditory system. Journal of Clinical Investigation 104 291-300.

Bakker O 1998 LUMI-imager F1 Lab Protocols. Berlin, Heidelberg, New York: Springer Verlag.

Baxter JD, Dillmann WH, West BL, Huber R, Furlow JD, Fletterick RJ, Webb P, Apriletti JW \& Scanlan TS 2001 Selective modulation of thyroid hormone receptor action. Journal of Steroid Biochemistry and Molecular Biology 76 31-42.

Birchmeier C \& Birchmeier W 1993 Molecular aspects of mesenchymal-epithelial interactions. Annual Review of Cell Biology 9 511-540.

Bradley DJ, Towle HC \& Young WSd 1992 Spatial and temporal expression of $\alpha$ - and $\beta$-thyroid hormone receptor mRNAs, including the $\beta 2$-subtype, in the developing mammalian nervous system. Journal of Neuroscience 12 2288-2302.

Brard J 1990. Morphogenesis, the Cellular and Molecular Processes of Developmental Anatomy, Cambridge: Cambridge University Press.

Chassande O 2003 Do unliganded thyroid hormone receptors have physiological functions? Journal of Molecular Endocrinology 31 9-20.

Cheng SY 2000 Multiple mechanisms for regulation of the transcriptional activity of thyroid hormone receptors. Reviews in Endocrine and Metabolic Disorders 1 9-18.

Dubois JD \& Dussault JH 1977 Ontogenesis of thyroid function in the neonatal rat. Thyroxine (T4) and triiodothyronine (T3) production rates. Endocrinology $101435-441$.

Ercan-Fang S, Schwartz HL \& Oppenheimer JH 1996 Isoform-specific 3,5,3'-triiodothyronine receptor binding capacity and mRNA content in rat adenohypophysis: effect of thyroidal state and comparison with extrapituitary tissues. Endocrinology 137 3228-3233.

Flamant F \& Samarut J 2003 Thyroid hormone receptors: lessons from knockout and knock-in mutant mice. Trends in Endocrinology and Metabolism 14 85-90.

Forrest D, Hanebuth E, Smeyne RJ, Everds N, Stewart CL, Wehner JM \& Curran T 1996 Recessive resistance to thyroid hormone in mice lacking thyroid hormone receptor $\beta$ : evidence for tissue-specific modulation of receptor function. EMBO Journal 15 3006-3015.

Fraichard A, Chassande O, Plateroti M, Roux JP, Trouillas J, Dehay C, Legrand C, Gauthier K, Kedinger M, Malaval L et al. 1997 The T3R $\alpha$ gene encoding a thyroid hormone receptor is essential for postnatal development and thyroid hormone production. EMBO Journal 16 4412-4420. 
Glinoer D 2001 Potential consequences of maternal hypothyroidism on the offspring: evidence and implications. Hormone Research $\mathbf{5 5}$ 109-114.

Gudernatsch JF 1912 Feeding experiments on tadpoles I. The influence of specific organs given as food on growth and differentiation. Archiv fr Entwicklungsmechanik der Organismen 35457.

Hashimoto K, Curty FH, Borges PP, Lee CE, Abel ED, Elmquist JK, Cohen RN \& Wondisford FE 2001 An unliganded thyroid hormone receptor causes severe neurological dysfunction. PNAS $\mathbf{9 8}$ 3998-4003.

Hodin RA, Lazar MA, Wintman BJ, Darling DS, Koenig RJ, Larsen PR, Moore DD \& Chin WW 1989 Identification of a thyroid hormone receptor that is pituitary-specific. Science 244 76-79.

Jonker A, de Boer PA, van den Hoff MJ, Lamers WH \& Moorman AF 1997 Towards quantitative in situ hybridization. Journal of Histochemistry and Cytochemistry 45 413-423.

Lane JT, Godbole M, Strait KA, Schwartz HL \& Oppenheimer JH 1991 Prolonged fasting reduces rat hepatic $\beta 1$ thyroid hormone receptor protein without changing the level of its messenger ribonucleic acid. Endocrinology 129 2881-2885.

Lechan RM, Qi Y, Berrodin TJ, Davis KD, Schwartz HL, Strait KA, Oppenheimer JH \& Lazar MA 1993 Immunocytochemical delineation of thyroid hormone receptor $\beta 2$-like immunoreactivity in the rat central nervous system. Endocrinology 132 2461-2469.

Li M \& Boyages SC 1997 Expression of $\beta 2$-thyroid hormone receptor in euthyroid and hypothyroid rat pituitary gland: an in situ hybridization and immunocytochemical study. Brain Research 773 125-131.

Macchia PE, Takeuchi Y, Kawai T, Cua K, Gauthier K, Chassande O, Seo H, Hayashi Y, Samarut J, Murata Y et al. 2001 Increased sensitivity to thyroid hormone in mice with complete deficiency of thyroid hormone receptor $\alpha$. PNAS 98 349-354.

Moller A \& Jansson JK 1997 Quantification of genetically tagged cyanobacteria in Baltic Sea sediment by competitive PCR. BioTechniques 22 512-518.

Moorman AFM, de Boer PAJ, Ruijter JM, Hagoort J, Franco D \& Lamers WH 2000 Radio-isotopic in situ Hybridization on tissue sections: practical aspects and quantification. In Developmental Biology Protocols, vol 137, pp 97-115. Eds RS Tuan \& CW Lo. Totowa, NJ: Humana Press Inc. (vol 3, ch 11).

Morreale de Escobar G, Calvo R, Obregon MJ \& Escobar del Rey F 1990 Contribution of maternal thyroxine to fetal thyroxine pools in normal rats near term. Endocrinology 126 2765-2767.

Morreale de Escobar G, Obregon MJ \& Escobar del Rey F 2004 Role of thyroid hormone during early brain development. European Journal of Endocrinology 151 25-37.

Oppenheimer JH \& Schwartz HL 1997 Molecular basis of thyroid hormone-dependent brain development. Endocrine Reviews 18 $462-475$.

O'Shea PJ \& Williams GR 2002 Insight into the physiological actions of thyroid hormone receptors from genetically modified mice. Journal of Endocrinology 175 553-570.

Plateroti M, Chassande O, Fraichard A, Gauthier K, Freund JN, Samarut J \& Kedinger M 1999 Involvement of T3Ralpha- and betareceptor subtypes in mediation of T3 functions during postnatal murine intestinal development. Gastroenterology 116 1367-1378.

Plateroti M, Gauthier K, Domon-Dell C, Freund JN, Samarut J \& Chassande O 2001 Functional interference between thyroid hormone receptor alpha $(\mathrm{TR} \alpha)$ and natural truncated TR $\Delta \alpha$ isoforms in the control of intestine development. Molecular and Cellular Biology 21 4761-4772.

Rodd C, Schwartz HL, Strait KA \& Oppenheimer JH 1992 Ontogeny of hepatic nuclear triiodothyronine receptor isoforms in the rat. Endocrinology 131 2559-2564.

Schwartz HL, Strait KA, Ling NC \& Oppenheimer JH 1992 Quantitation of rat tissue thyroid hormone binding receptor isoforms by immunoprecipitation of nuclear triiodothyronine binding capacity. Journal of Biological Chemistry 267 11794-11799.
Schwartz HL, Lazar MA \& Oppenheimer JH 1994 Widespread distribution of immunoreactive thyroid hormone $\beta 2$ receptor (TR $\beta 2)$ in the nuclei of extrapituitary rat tissues. Journal of Biological Chemistry 269 24777-24782.

Sternberger LA, Hardy PH Jr, Cuculis JJ \& Meyer HG 1970 The unlabeled antibody enzyme method of immunohistochemistry: preparation and properties of soluble antigen-antibody complex (horseradish peroxidase-antihorseradish peroxidase) and its use in identification of spirochetes. Journal of Histochemistry and Cytochemistry 18 315-333.

van Straaten HWM, He Y, van Duist MM, Labruyère WT, Vermeulen JLM, van Dijk PJ, Ruijter JM, Lamers WH \& Hakvoort TBM 2006 Cellular concentrations of glutamine synthetase in murine organs. Biochemistry and Cell Biology 84 215-231.

Strait KA, Schwartz HL, Perez-Castillo A \& Oppenheimer JH 1990 Relationship of c-erbA mRNA content to tissue triiodothyronine nuclear binding capacity and function in developing and adult rats. Journal of Biological Chemistry 265 10514-10521.

Tata JR 1999 Amphibian metamorphosis as a model for studying the developmental actions of thyroid hormone. Biochimie 81 359-366.

Tuca A, Giralt M, Villarroya F, Vinas O, Mampel T \& Iglesias R 1993 Ontogeny of thyroid hormone receptors and c-erbA expression during brown adipose tissue development: evidence of fetal acquisition of the mature thyroid status. Endocrinology 132 1913-1920.

van Tuyl M, Blommaart PE, de Boer PA, Wert SE, Ruijter JM, Islam S, Schnitzer J, Ellison AR, Tibboel D, Moorman AF et al. 2004 Prenatal exposure to thyroid hormone is necessary for normal postnatal development of murine heart and lungs. Developmental Biology 272 104-117.

Weiss RE, Murata Y, Cua K, Hayashi Y, Seo H \& Refetoff S 1998 Thyroid hormone action on liver, heart, and energy expenditure in thyroid hormone receptor $\beta$-deficient mice. Endocrinology 139 4945-4952.

Wikstrom L, Johansson C, Salto C, Barlow C, Campos Barros A, Baas F, Forrest D, Thoren P \& Vennstrom B 1998 Abnormal heart rate and body temperature in mice lacking thyroid hormone receptor $\alpha 1$. EMBO Journal 17 455-461.

Williams GR 2000 Cloning and characterization of two novel thyroid hormone receptor $\beta$ isoforms. Molecular and Cellular Biology 20 8329-8342.

Wood WM, Dowding JM, Haugen BR, Bright TM, Gordon DF \& Ridgway EC 1994 Structural and functional characterization of the genomic locus encoding the murine $\beta 2$ thyroid hormone receptor. Molecular Endocrinology 8 1605-1617.

Yen PM 2001 Physiological and molecular basis of thyroid hormone action. Physiological Reviews 81 1097-1142.

Yen PM, Ando S, Feng X, Liu Y, Maruvada P \& Xia X 2006 Thyroid hormone action at the cellular, genomic and target gene levels. Molecular and Cellular Endocrinology 121-127.

Zandieh Doulabi B, Platvoet-terSchiphorst M, van Beeren HC, Labruyère WT, Lamers WH, Fliers E, Bakker O \& Wiersinga WM 2002 TR $\beta 1$ protein is preferentially expressed in the pericentral zone of rat liver and exhibits marked diurnal variation. Endocrinology 143 979-984.

Zandieh-Doulabi B, Dop E, Schneiders M, Schiphorst MP, Mansen A, Vennstrom B, Dijkstra CD, Bakker O \& Wiersinga WM 2003 Zonal expression of the thyroid hormone receptor $\alpha$ isoforms in rodent liver. Journal of Endocrinology 179 379-385.

Zhang J \& Lazar MA 2000 The mechanism of action of thyroid hormones. Annual Review of Physiology 62 439-466.

Received in final form 13 February 2007

Accepted 16 February 2007

Made available online as an Accepted Preprint 28 February 2007 